\title{
Pengaruh Pemberian Susu Sapi Bubuk terhadap Kadar MDA Hepar pada Tikus Putih (Rattus Novergicus Strain Wistar) Jantan Model Diabetes Melitus Tipe 2
}

\section{Effect of Cow Milk Powder Administration on Hepatic MDA Levels of White Male Rats (RattusNovergicusWistar Strain) Model of Type 2 Diabetes Mellitus}

\author{
Adi Lukas K $K^{1}$, Fajar Ari N², Prasetyo Adi ${ }^{3}$ \\ ${ }^{1}$ Program Studi Ilmu Gizi Fakultas Kedokteran Universitas Brawijaya Malang \\ ²Laboratorium Ilmu Gizi Fakultas Kedokteran Universitas Brawijaya Malang \\ ${ }^{3}$ Program Studi Farmasi Fakultas Kedokteran Universitas Brawijaya Malang
}

\begin{abstract}
ABSTRAK
Susu sapi bubuk mengandung kalsium, dan vitamin D yang dapat mencegah peningkatan kadar Malondialdehyde (MDA) pada diabetes melltus tipe 2 melalui mekanisme perbaikan sekresi dan sensitivitas insulin. Susu sapi bubuk mampu menurunkan kondisi stress oksidatif pemicu peningkatan kadar MDA. Tujuan penelitian ini untuk mengetahui pengaruh pemberian susu sapi bubuk terhadap kadar MDA hepar pada tikus wistar model diabetes melitus tipe 2. Penelitian ini adalah penelitian eksperimental post test only control group design menggunakan 30 tikus wistar model diabetes melitus tipe 2. Selama 90 hari, kelompok perlakuan diberikan susu sapi bubuk 0,9g (P1); 1,8g (P2); dan 2,7g (P3) per hari. selanjutnya pada hari ke-91 dilakukan pengukuran kadar MDA dari jaringan hepar dengan spektrofotometer. Hasil menunjukkan terdapat pengaruh pemberian susu sapi bubuk dengan berbagai dosis terhadap kadar MDA jaringan hepar tikus $(p=0,003)$, dengan dosis efektif adalah $1,8 \mathrm{~g} /$ hari karena dapat mencegah peningkatan kadar MDA mendekati kelompok negatif.
\end{abstract}

Kata Kunci: Diabetes melitus tipe 2, Malondialdehyde (MDA), susu sapi bubuk

\section{ABSTRACT}

Cow milk powder which contains various components such as calcium and vitamin $D$ can prevent the rise of Malondialdehyde (MDA) in diabetes mellitus type 2 through the mechanism of secession correction and insulin sensitivity. Dairy milk powder decreases oxidative stress condition which is the trigger of increasing MDA levels. The aim of this study is to determine the effect of milk powder on MDA hepatic tissue levels of Wistar rat model of diabetes mellitus type 2. This is an experimental study using post test only control group design utilizing 30 Wistar rats model of diabetes mellitus type 2. For 90 days, the treatment groups were fed with $0,9 g(P 1), 1,8 g(P 2)$, and 2,7g (P3) cow milk powder per day, on day $91^{\text {th }} \mathrm{MDA}$ hepatic tissue levels were measured with spectrophotometer. The result shows there was an effect of dairy milk powder with various doses in MDA levels in the rat's liver tissue $(p=0,003)$, and the most effective dose was $1,8 \mathrm{~g} /$ day because it could prevent the rise of MDA levels in liver tissue.

Keywords: Cow milk powder, malondialdehyde (MDA), type 2 diabetes mellitus

Jurnal Kedokteran Brawijaya, Vol. 28, No. 3, Februari 2015; Korespondensi: Fajar Ari N. Laboratorium Ilmu Gizi Fakultas Kedokteran Universitas Brawijaya Malang, Jl. Veteran Malang Tel. (0341)569117 Email:fanmerah@gmail.com 


\section{PENDAHULUAN}

Diabetes melitus (DM) adalah penyakit metabolik dengan beberapa etiologi yang ditandai dengan hiperglikemia kronis akibat adanya gangguan metabolisme karbohidrat, lemak, dan protein. Gangguan ini terjadi karena kelainan sekresi insulin, kerja insulin pada reseptor sel, maupun kedua-duanya yang menyebabkan tingginya kadar gula dalam darah (1). International Diabetes Federation (IDF) pada tahun 2013, menyebutkan jumlah penderita DM dari 382 juta orang pada tahun 2013 meningkat menjadi 592 juta orang pada tahun 2035, dimana $80 \%$ ditemukan pada penduduk negara berkembang pada usia 40-59 tahun. Indonesia berada pada peringkat 7 pada tahun 2013 sebagai penyandang penderita DM terbesar. WHO memprediksi kenaikan jumlah penderita DM di Indonesia dari 8,5 juta orang pada tahun 2013 menjadi sekitar 14,1 juta orang pada tahun 2035 (2).

Hiperglikemia sebagai salah satu tanda diabetes melitus dapat menyebabkan pembentukan Reactive Oxygen Species (ROS), dimana hal ini akan meningkatkan stres oksidatif dan kejadian komplikasi pada diabetes melitus (3). Interaksi ROS dengan lipid bilayer akan menghasilkan peroksidasi lipid. Hasil akhir reaksi peroksidasi lipid adalah senyawa aldehid, dimana yang terbesar adalah Malondialdehyde (MDA) yang dapat digunakan sebagai biomarker derajat stres oksidatif pada diabetes melitus (4).

Susu sapi adalah bahan makanan sumber vitamin D dan kalsium. Vitamin D dapat mengurangi radikal ROS dengan cara mengontrol gula darah terkait hiperglikemia (5). Vitamin $\mathrm{D}$ bekerja menghambat hiperglikemia dengan meningkatkan kemampuan reseptor insulin untuk mentranspor glukosa ke dalam sel dan berperan meregulasi kalsium ekstrasel dalam menjaga kalsium influk dalam batas normal pada sel beta serta menyediakan $\mathrm{Ca}^{2+}$ yang adekuat.

Hal ini mempengaruhi sekresi insulin karena sekresi insulin merupakan proses yang bergantung pada ion $\mathrm{Ca}^{2+}$ (Calcium dependent process) (6). Dengan adanya mekanisme vitamin D terhadap kerja insulin, dalam perbaikan fungsi dari sel beta pankreas dan perbaikan resistansi insulin dapat mengontrol hiperglikemia. Dengan kata lain terbentuknya radikal ROS akan menurun dan kadar MDA sebagai hasil peroksidasi lipid juga akan menurun (7).

Susu sapi sebagai sumber vitamin $D$ dan kalsium belum banyak diketahui manfaatnya untuk penyakit degenerative. Itulah sebabnya menurut penelitian pada pola konsumsi pangan penderita diabetes melituss di rumah sakit cipto mangunkusumo, diketahui bahwa sebagian besar responden tidak pernah mengkonsumsi susu. Sementara responden yang mengkonsumsi susu dan produk olahannya, hanya mengkonsumsinya dengan frekuensi jarang (8).

Tujuan penelitian ini adalah untuk mengetahui pengaruh pemberian susu sapi bubuk (sumber vitamin D) dalam menurunkan kadar Malondialdehyde (MDA) hepar tikus wistar jantan model diabetes melitus tipe 2 .

\section{METODE}

Jenis penelitian yang digunakan adalah penelitian eksperimental in vivo pada hewan coba tikus Wistar jantan dengan desain penelitian posttest only control group design. Sampel penelitian sebanyak 30 tikus putih Rattus Novergicus Strain Wistar jantan, umur \pm 2 bulan, sehat, dengan berat badan 180-250gram. Tikus dibagi secara acak menjadi 5 kelompok dan diberi perlakuan selama 94 hari. Kelompok kontrol negatif $(\mathrm{K}(-))$ diberikan diet normal tanpa diinduksi streptozotocin (STZ). Kelompok kontrol positif $(\mathrm{K}(+))$ diberikan diet tinggi lemak + induksi streptozotocin (STZ). Kelompok perlakuan diberikan diet tinggi lemak + induksi streptozotocin (STZ) + susu sapi bubuk dosis (P1) 0,9gram/hari (9IU vitamin D dan $10,8 \mathrm{mg}$ kalsium), (P2) 1,8gram/hari (18IU vitamin D dan $21,6 \mathrm{mg}$ kalsium) dan (P3) 2,7gram/hari (27IU vitamin D dan 32,4mg kalsium).

Diet normal dibuat dari campuran PARS 53\% (dengan kandungan protein $11 \%$, lemak $4 \%$ ), tepung terigu $23,5 \%$, dan air 23,5\%. Diet tinggi lemak dibuat dari campuran PARS $50 \%$, tepung terigu $25 \%$, kuning telur bebek $5 \%$, lemak kambing $10 \%$, minyak kelapa $1 \%$, minyak babi $8,9 \%$, dan asam kolat $0,1 \%$. Susu sapi bubuk diberikan secara oral dicampur dengan pakan isokalorik dimana tiap 40gram mengandung energy $160 \mathrm{kkal}$, lemak 2,5gram, protein 6 gram, karbohidrat 28gram, vitamin D 400 IU, dan kalsium $500 \mathrm{mg}$. Pemberian diet tinggi lemak sebanyak 40gram/hari (kelompok 2 sampai dengan 5) dilakukan selama 4 minggu, dilanjutkan satu kali injeksi streptozotocin (STZ) dosis $40 \mathrm{mg} / \mathrm{kgBB}$ secara intraperitoneal. Kadar glukosa darah tikus diukur 3 hari setelah injeksi STZ dan dinyatakan diabetes jika glukosa darah sewaktu $\geq 200 \mathrm{mg} / \mathrm{dL}$ (9). Setelah dinyatakan diabetes, tikus (kelompok 3 sampai dengan 5) diberi susu sapi bubuk dan pakan normal selama 8 minggu.

Pada hari ke 94 tikus diukur kadar MDA nya dengan pembedahan dan mengambil organ hepar. Hepar diambil $100 \mathrm{mg}$ dan dihomogenasi. Sampel hepar ditambahkan $1 \mathrm{~mL}$ akuades. Pemeriksaan MDA dilakukan dengan penambahan Thiobarbituric acid (TCA) 100\% 100uL, Nathio 10\% 100uL, HCL 1N 250uL, dan akuades 450uL. Kemudian dipanaskan $100^{\circ} \mathrm{C}$ selama 10 menit, disentrifuge 3000rpm selama 10 menit, dan dibaca dengan panjang gelombang $500-600 \mathrm{~nm}$. Pemeriksaan MDA dengan menggunakan spektrofotometer dan hasil pemeriksaan dianalisis dengan menggunakan SPSS 17 dengan tingkat signifikansi 0,05 dan taraf kepercayaan 95\% $(\alpha=0,05)$.

\section{HASIL}

Tikus yang digunakan dalam penelitian ini berusia 2-3 bulan, dengan jenis kelamin jantan, bulu putih, bersih, lebat, dan kondisi sehat, serta tingkah laku normal. Rerata berat badan awal tertinggi pada tikus kelompok kontrol positif $(\mathrm{K}+)$ sebesar 203,33gram, sedangkan yang terendah pada kelompok perlakuan 2 sebesar 191,67gram.

Berdasarkan hasil uji normalitas, berat badan awal tikus menunjukkan hasil yang bermakna, dimana $p>0,05$ (Kontrol negatif $p=0,091$, kontrol positif $p=0,473$, perlakuan $1 p=0,323$, perlakuan $2 p=0,421$, dan perlakuan $3 p=0,643)$. Berdasarkan uji homogenitas, berat badan awal tikus menunjukkan hasil $p>0,05(p=0,141)$. Dari hasil uji diatas dapat disimpulkan bahwa sampel berdistribusi normal dan homogen serta sesuai dengan kriteria inklusi.

\section{Perubahan Berat Badan Tikus Selama Penelitian}

Rerata berat badan akhir tikus tertinggi pada kelompok kontrol negatif (K-) sebesar 351,67gram, sedangkan rerata 
Tabel 1. Hasil Penelitian

\begin{tabular}{|c|c|c|c|c|c|}
\hline Parameter & $K(-)$ & $K(+)$ & P1 & $\mathbf{P 2}$ & P3 \\
\hline \multicolumn{6}{|l|}{ Berat badan tikus : } \\
\hline - BB awal & 193,33 & 203,33 & 202,5 & 191,67 & 201,67 \\
\hline - BB akhir & 351,67 & 285 & 291,57 & 264 & 285 \\
\hline Asupan pakan rata -rata (g) & 29,97 & 35,43 & 36,61 & 36,46 & 37,96 \\
\hline Asupan susu sapi bubuk (g) & - & - & 0,82 & 1,71 & 2,53 \\
\hline Asupan energi rata -rata (kal) & 86,21 & 107,11 & 110,71 & 108,61 & 115,02 \\
\hline Asupan lemak rata -rata (g) & 0,82 & 2,35 & 2,47 & 2,24 & 2,58 \\
\hline \multicolumn{6}{|c|}{ Perubahan kadar glukosa darah : } \\
\hline - GD akhir & - & 272,5 & 262,5 & 342,8 & 334,25 \\
\hline - GD past-stz & - & 399,5 & 422,33 & 414,6 & 350 \\
\hline - GD pre-stz & - & 107,75 & 108,5 & 112,2 & 112,25 \\
\hline Rerata kadar MDA tikus & $148,167 \pm 8,47$ & $208,375 \pm 38,58$ & $109,5 \pm 5,42$ & $146 \pm 11,91$ & $129 \pm 27,53$ \\
\hline
\end{tabular}

berat badan akhir tikus terendah pada kelompok perlakuan 2 sebesar 264 gram. Hasil uji normalitas menunjukkan bahwa data berdistribusi normal $(p=0,329)$ dan homogen $(p=0,579)$. Hal ini menunjukkan pemberian pakan isokalorik menghasilkan pola pertumbuhan yang sama pada tikus (Tabel 1 ).

\section{Asupan Pakan dan Susu Bubuk Tikus}

Tingkat asupan pakan merupakan banyaknya pakan dalam berat kering yang dikonsumsi oleh tikus dibandingkan dengan kebutuhan. Kebutuhan pakan tikus sehari dalam berat kering adalah sebesar 40 gram. Rerata asupan tertinggi pada kelompok perlakuan 3 sebesar 37,96 gram dan terendah sebesar 29,97 pada kelompok kontrol negatif $\mathrm{K}(-)$. Analisis terhadap asupan pakan tikus menggunakan uji One Way ANOVA menunjukkan bahwa ada perbedaan rerata tingkat asupan pakan yang bermakna pada kelima kelompok perlakuan dengan nilai $p=0,0001(\alpha=0,05)$. Pada penelitian ini, rerata tingkat asupan pakan pada kelompok K(+), P1, P2, dan P3 berbeda secara bermakna terhadap normal Tabel 1.

Asupan susu bubuk diperoleh dari asupan pakan dibagi dengan pakan yang diberikan dan dikalikan dengan dosis susu sapi bubuk yang diberikan setiap harinya. Analisis uji normalitas menunjukkan bahwa asupan susu tidak berdistribusi normal $p=0,031$ dikarenakan dosis susu bubuk yang diberikan berbeda. Rerata asupan susu bubuk dapat dilihat pada Tabel 1. Hasil uji Kruskal-Wallis menunjukkan adanya perbedaan yang bermakna antar kelompok perlakuan $1(\mathrm{P} 1)$, perlakuan 2 (P2), perlakuan 3 (P3) dengan nilai $p=0,0001(\alpha=0,05)$.

\section{Asupan Energi dan Lemak Tikus Selama Penelitian}

Asupan energi tikus tertinggi pada kelompok perlakuan 3 (P3) sebesar 115,02 kalori dan terendah sebesar 86,21 kalori pada kelompok kontrol negatif. Analisis terhadap rerata asupan energi menggunakan uji One Way ANOVA menunjukkan bahwa ada perbedaan rerata tingkat asupan energi yang bermakna pada kelima kelompok perlakuan dengan nilai $p=0,0001(\alpha=0,05)$. Rerata asupan energi dapat dilihat pada Tabel 1.

Pada penelitian ini, rerata asupan energi pada kelompok $\mathrm{K}$ (+), P1, P2, dan P3 berbeda secara bermakna terhadap kelompok K (-). Asupan lemak merupakan jumlah lemak rerata yang dikonsumsi tikus selama 94 hari pemberian diet normal untuk kelompok $\mathrm{K}(-)$ dan diet normal +HFD untuk kelompok K (+) dan perlakuan (P1, P2, dan P3). Rerata asupan lemak dapat dilihat pada Tabel 1.
Rerata asupan lemak tertinggi ditunjukkan pada kelompok perlakuan 3 (P3) sebesar 2,58gram dan terendah sebesar 0,82 gram pada kelompok kontrol negatif. Analisis asupan lemak tikus menggunakan uji One Way ANOVA menunjukkan bahwa ada perbedaan rerata tingkat asupan pakan yang bermakna pada kelima kelompok perlakuan dengan nilai $p=0,0001(\alpha=0,05)$. Pada penelitian ini, rerata tingkat asupan kemak pada kelompok $\mathrm{K}(+), \mathrm{P} 1, \mathrm{P} 2$, dan P3 berbeda secara bermakna terhadap kelompok K (-).

\section{Perubahan Kadar Glukosa Tikus}

Kadar glukosa darah tikus diukur pada saat sebelum induksi STZ untuk memastikan bahwa tikus memiliki kadar glukosa darah normal. Rerata kadar glukosa darah setelah induksi STZ, GDP meningkat menjadi $>200 \mathrm{mg} / \mathrm{dl}$, hal ini menunjukkan bahwa semua kelompok perlakuan berada dalam kondisi diabetes melitus.

Hasil uji normalitas menunjukkan bahwa glukosa darah setelah STZ berdistribusi normal $p=0,628$ ( $p>0,05)$. Uji homogenitas menunjukkan bahwa data homogen $p=0,055$ $(p>0,05)$. Selama 54 hari intervensi, setiap minggu dilakukan pengukuran kadar glukosa darah, hal ini terus berlanjut sampai minggu terakhir sebelum pembedahan. Perubahan kadar glukosa darah tikus dapat dilihat pada Tabel 1.

Pada akhir intervensi kadar glukosa darah tikus masingmasing kelompok perlakuan mengalami perubahan. Rerata penurunan gula darah tertinggi ditunjukkan pada kelompok P1 $(262,5 \mathrm{mg} / \mathrm{dL})$. Hasil uji normalitas menunjukkan bahwa gula darah akhir berdistribusi normal $p=0,189(p>0,05)$. Uji homogenitas menunjukkan bahwa data homogen $p=0,552(p>0,05)$. Uji paired-t-test untuk mengetahui perbedaan gula darah setelah STZ dengan gula darah akhir menunjukkan adanya perbedaan yang bermakna antara gula darah setelah STZ dengan gula darah akhir $p=0,048(p<0,05)$. Dengan demikian dapat dikatakan bahwa terdapat penurunan kadar gula darah yang bermakna pada tiap kelompok P1, P2 dan P3 dibandingkan dengan gula darah setelah STZ.

\section{Kadar Malondialdehyde (MDA) Tikus}

Rerata kadar MDA tertinggi pada kelompok $\mathrm{K}(+)$ yaitu sebesar $208,375 \pm 38,58 \mathrm{ug} / \mathrm{ml}$ dan terendah pada kelompok P1 yaitu 109,500 $\pm 5,42 \mathrm{ug} / \mathrm{ml}$. Hasil uji normalitas dan homogenitas menunjukkan bahwa kadar MDA berdistribusi normal $p=0,182(p>0,05)$ dan tidak homogen $p=0,001(p<0,05)$. Berdasarkan hasil uji statistik 
Kruskal-Wallis menunjukkan bahwa ada perbedaan rerata kadar MDA yang bermakna pada kelima kelompok perlakuan dengan nilai $p=0,003(\alpha=0,05)$. Rerata kadar MDA tikus dapat dilihat pada Tabel 1.

Pada penelitian ini, kadar MDA kelompok tikus tanpa pemberian susu sapi bubuk $\mathrm{K}(+)$ mengalami peningkatan secara bermakna $p=0,011(p<0,05)$ dibandingkan dengan kadar MDA pada tikus normal K (-). Kadar MDA Kelompok tikus dengan pemberian per oral susu sapi bubuk dosis 0,9 gram/hari (P1), dosis 1,8 gram/hari (P2), dan dosis 2,7gram/hari (P3) mengalami penurunan dibandingkan dengan kelompok $(\mathrm{K}+)$ dibuktikan dengan nilai $p<0,05$. Hal ini menunjukkan adanya perbedaan yang bermakna kadar MDA jaringan hepar pada ketiga kelompok perlakuan $\mathrm{P} 1, \mathrm{P} 2, \mathrm{P} 3$ dibandingkan dengan kelompok kontrol positif $\mathrm{K}$ (+). Kadar MDA kelompok P2 mengalami peningkatan jika dibandingkan dengan kelompok P1 dan kelompok P3. Kadar MDA hepar kelompok P2 dibanding kelompok P1 menunjukkan perbedaan yang bermakna dibuktikan dengan nilai $p=0,009(p<0,05)$. Kadar MDA kelompok P2 mendekati kelompok P3, dibuktikan tidak adanya perbedaan yang bermakna antara kadar MDA kelompok $P 2$ dibanding $P 3$, dengan nilai $p=0,327(p>0,05)$. Hasil ini menunjukkan bahwa pemberian susu bubuk meningkatkan kadar MDA hepar pada tikus model diabetes dengan dosis optimum 1,8 gram/hari.

\section{DISKUSI}

Perubahan Berat Badan dan Asupan Pakan Tikus Selama Penelitian

Dibandingkan dengan rerata berat badan akhir pada kelompok perlakuan $\mathrm{K}(-)$ yaitu 351,67 gram, tikus dengan diabetes melitus $(\mathrm{K}(+), \mathrm{P} 1, \mathrm{P} 2, \mathrm{P} 3)$ menunjukkan rerata berat badan akhir tikus yang lebih rendah yaitu masingmasing 285gram, 291,67gram, 264gram, dan 285gram.

Penurunan berat badan disebabkan karena tubuh tidak mampu menggunakan glukosa sebagai sumber energi akibat kekurangan insulin (10). Kebutuhan energi kemudian diperoleh dari lemak diberbagai jaringan dimobilisasi dan didegradasi untuk menghasilkan energi. Kehilangan lemak menyebabkan berat badan menurun (11). Sumber energi juga diambil dari otot ataupun hati melalui proses glukoneogenesis sehingga keadaan ini yang menyebabkan berat badan menurun (12). Tingkat stress pada tikus diabetes akibat hiperglikemia yang meningkatkan stress oksidatif, mempengaruhi nafsu makan dan berdampak pada penurunan berat badan (13).

Rerata asupan pakan tertinggi pada pemberian asupan susu bubuk kelompok P3 sebesar 37,96gram dan terendah pada kelompok (K-) sebesar 29,97gram. Hal ini menunjukkan bahwa asupan pakan kelompok diabetes melitus lebih tinggi dari pada kelompok normal karena terjadi gangguan metabolisme glukosa. Glukosa tidak dapat masuk kedalam sel, akibatnya individu tersebut akan terus merasa lapar (polifagia) (10). Resistensi insulin merupakan penyebab glukosa tidak dapat masuk ke dalam sel karena jaringan target seperti otot tidak mampu merespon adanya insulin. Hal ini karena tingginya asam lemak bebas akan mengakibatkan terjadinya fosforilasi serin pada reseptor insulin jaringan target, sehingga akan mengurangi aktivitas insulin signaling pathway (GLUT-4) yang berfungsi membawa glukosa dari reseptor insulin ke dalam sel (5).
Diet normal dengan komposisi PARS 53\%, tepung terigu 23,5\%, air 23,5\% memiliki kandungan lemak 0,93gram/40 gram. Sedangkan diet aterogenik dengan komposisi kuning telur bebek $5 \%$, lemak kambing $10 \%$, minyak kelapa $1 \%$, minyak babi $8,9 \%$, asam kolat $0,1 \%$, comfeed PARS $50 \%$, dan tepung terigu $25 \%$ memiliki kandungan lemak 9,59gram/40 gram. Sehingga asupan lemak kelompok K (-) dengan diet normal yang terendah yaitu 0,82gram.

\section{Kadar Glukosa Darah Tikus Selama Penelitian}

Hasil penelitian menunjukkan bahwa tikus setelah induksi STZ mengalami diabetes melitus dibuktikan dengan kadar gula darah puasa pada kelompok $\mathrm{K}(+)=399,5 \mathrm{mg} / \mathrm{dL}$, $\mathrm{P} 1=422,33 \mathrm{mg} / \mathrm{dL}, \mathrm{P} 2=414,6 \mathrm{mg} / \mathrm{dL}$, dan $\mathrm{P} 3=334,25 \mathrm{mg} / \mathrm{dL}$. Pemberian diet tinggi lemak selama 4 minggu akan membuat resistensi insulin pada hewan coba. Induksi dosis rendah STZ (35-45 mg/kgBB) menyebabkan gangguan sintesis DNA, merusak dan menghambat siklus krebs pada mitokondria sel beta, dan menurunkan ATP sehingga terjadi gangguan sekresi insulin $(13,14)$. Hal ini serupa dengan etiologi non-genetik dari diabetes melitus tipe 2, dimana diet tinggi lemak yang dikombinasikan dengan dosis rendah STZ pada hewan coba cocok dengan karakteristik DM tipe 2 yang mengalami resistensi dan defisiensi insulin (14).

Kadar glukosa darah akhir tikus mengalami penurunan pada kelompok diabetes melitus, yaitu $\mathrm{P} 1=262,5 \mathrm{mg} / \mathrm{dL}$, $\mathrm{P} 2=342,8 \mathrm{mg} / \mathrm{dL}$, dan $\mathrm{P} 3=334,25 \mathrm{mg} / \mathrm{dL}$. Hal ini menunjukkan konsumsi produk susu dapat menurunkan gula darah puasa pada penderita diabetes melitus, dimana peran penurunan gula darah puasa tidak lepas dari kandungan vitamin D dan kalsium dalam produk susu (1517).

\section{Kadar Malondialdehyde (MDA) Tikus}

Malondialdehyde (MDA) sebagai salah satu produk hasil peroksidasi lipid adalah indikator untuk mengukur adanya stres oksidatif dalam tubuh dan juga menunjukkan jumlah radikal bebas dalam tubuh. Pada penelitian ini kadar MDA pada kelompok diabetes tanpa pemberian susu sapi bubuk $\mathrm{K}(+)$ menunjukkan peningkatan dibanding dengan kelompok lain, yaitu 208,375 $\pm 38,58 \mathrm{ug} / \mathrm{mL}$.

Hiperglikemia meningkatkan stress oksidatif melalui autooksidasi glukosa menghasilkan $\alpha$-hidroksi-aldehid, dimana akan membentuk radikal reactive oxygen species (ROS) yaitu superoksida $\left(\mathrm{O}_{2}^{-}\right)$, radikal hidroksil $\left(\mathrm{OH}^{-}\right)$, dan hydrogen peroksida $\left(\mathrm{H}_{2} \mathrm{O}_{2}\right)$ (18). Kedua, hiperglikemia menyebabkan akumulasi sorbitol dan fruktosa karena peningkatan aktivitas aldose reductase dan penurunan NADPH intrasel. Hal ini akan menyebabkan penurunan antioksidan endogen yaitu glutation reductase (GSH) dan peningkatan NO-ROS (18). Ketiga, hiperglikemia akan meningkatkan glikosilasi protein yaitu ikatan aldehid glukosa mengikat amino dari protein. Hal ini menyebabkan pembentukan Advanced Glycation End Product (AGE) dan ROS pada sel vaskular. Keempat, hiperglikemia meningkatkan sintesis diasil gliserol (DAG) dan protein kinase $C$ (PKC) yang menyebabkan peningkatan radikal intrasel (superoksida dan peroksida) karena adanya peningkatan oksidasi NADPH (19). ROS jika bertemu dengan PUFA akan membentuk radikal lipid, radikal peroksil, dan berbagai senyawa aldehid (20).

Stress oksidatif akibat tingginya ROS karena adanya hiperglikemia kronis memicu terjadinya kerusakan DNA dan kerusakan membrane sel. Diabetes melitus tipe 2 
mengalami peningkatan kadar MDA dan peroksidasi lipid secara signifikan karena tidak diimbangi dengan peningkatan antioksidan endogen tubuh seperti glutathione, glutathione reduktase, glutathione peroksidase yang makin mengalami penurunan level $(18,21)$.

Pada penelitian ini diketahui bahwa kadar MDA jaringan hepar tikus secara bermakna turun pada ketiga kelompok tikus diabetes yang diberi susu (P1 dosis 0,9gram, $\mathrm{P} 2$ dosis 1,8gram, dan P3 dosis 2,7gram) dibandingkan dengan kelompok K (+). Penelitian ini juga menunjukkan bahwa pemberian per oral susu sapi dapat menurunkan kadar gula darah pada kelompok P1, P2, dan P3.

Mekanisme susu sapi bubuk dalam menurunkan hiperglikemia dan stres oksidatif tidak lepas dari komponen penting susu, yaitu protein susu, vitamin D dan kalsium yang dapat mempengaruhi sekresi dan sensitivitas insulin, sehingga secara tidak langsung dapat menghasilkan penurunan kadar MDA yang disebabkan oleh penurunan kadar gula darah. Protein susu (whey protein) memiliki sifat insulinotropik dan meningkatkan toleransi glukosa karena memiliki glikemik load rendah. Protein susu menstimulasi pengeluaran dari asam amino insulinotropik, IDF-1 (insulin-like-growth-factor 1), hormon inkretin, dan GIP (glucose-dependent insulinotropic polypeptide) yang dapat meningkatkan sensitivitas insulin serta pengeluaran insulin (22).

Vitamin D dalam susu secara langsung dapat meningkatkan kemampuan insulin dalam mentranspor glukosa dengan mengikat reseptor vitamin D pada sel beta pancreas. Vitamin D juga mengatur kalsium ekstrasel untuk menjaga influks kalsium dalam batas normal di dalam membrane sel beta dan menyediakan $\mathrm{Ca}^{2+}$ yang adekuat (23). Hal akan mempengaruhi sekresi insulin karena pengeluaran insulin sangat bergantung kalsium (Calcium-dependent process), sehingga perubahan fluks kalsium dapat memberikan efek negatif terhadap sekresi insulin (6). Kedua, keberadaan reseptor vitamin D di sel

\section{DAFTAR PUSTAKA}

1. World Health Organization. Definition, Diagnosis, and Classification of Diabetes Melitus and its Complications. Geneva: Department of Noncommunicable Disease Surveillance; 1999.

2. International Diabetes Federation. IDF Diabetes Atlas. (Online) 2013. http://www.idf.org/ diabetsatlas/5e/the-global-burden [diakses 28 Maret 2013].

3. Salem M, Kholoussi S, Kholoussi N, and Fawzy R. Malondialdehyde and Trace Element Levels in Patients with Type 2 Diabetes Melitus. Helenic Medicine. 2011;28(1):83-88.

4. Winarsih H. Antioksidan Alami dan Radikal. Yogyakarta: PT Kanisius; 2007; hal. 58.

5. Moreira TS and Hamadeh MJ. The Role of Vitamin D Deficiency in the Pathogenesis of Type 2 Diabetes Melitus. e- SPEN, the European e-Journal of Clinical Nutrition and Metabolism. 2010; 5(4): e155-e165.

6. Pittas AG, Lau J, Hu FB, and Hughes BD. Review: The Role of Vitamin D and Calcium in Type 2 Diabetes. A Systematic Review and Meta-Analysis. The Journal of Clinical Endocrinology and Metabolism. 2007; 92(6): beta dan jaringan target akan merespon bentuk aktif vitamin $\mathrm{D}\left(1,25(\mathrm{OH})_{2} \mathrm{D}\right)$ dengan cara mengikat reseptor vitamin $D$ pada sel beta sehingga dapat meningkatkan kerja insulin reseptor dan responsitas atau sensitivitas insulin untuk mentraspor glukosa dalam sel (24). Ketiga, kalsium dalam susu akan meningkatkan respon insulin pada jaringan adipose dan otot dengan cara meregulasi proses insulin mediated intrasel, sehingga menurunkan resistensi insulin $(23,25)$. Peningkatan sensitivitas pada reseptor insulin akan menurunkan hiperglikemia, sehingga kejadian stres oksidatif akibat tingginya radikal oksigen (ROS) dan kadar MDA akibat peroksidasi lipid juga menurun.

Peningkatan kadar MDA pada kelompok P2 yang lebih tinggi dibanding dengan kelompok P1 dan P3. Hal ini diakibatkan karena perbedaan masing-masing tikus dalam mencerna dan menyerap komponen susu (metabolisme), jenis susu yang dikonsumsi, apakah full-fat atau low-fat, dan jumlah konsentrasi profil lipid dalam tubuh (26). Pada kelompok P2 juga mengalami peningkatan LDL-Kolesterol dibanding kelompok P1 dan P2.

Semakin tinggi LDL serum maka resiko peningkatan MDA semakin besar, karena sebagian besar fosfolipid LDL lapisan lipidnya berupa PUFA sehingga mudah teroksidasi dan memicu terjadinya peroksidasi lipid (27). Korelasi yang positif antara MDA dan LDL juga ditunjukkan pada berbagai penelitian, dimana semakin tinggi kolesterol dan LDL maka semakin tinggi pula kadar MDA. Hal ini karena peningkatan peroksidasi lipid akibat tingginya LDL akan mengakibatkan peningkatan kadar MDA $(28,29)$.

Hasil penelitian ini menunjukkan pemberian susu sapi bubuk mampu menurunkan kadar Malondyaldehide (MDA) jaringan hepar tikus putih (Rattus norvegicus strain Wistar) jantan model diabetes melitus tipe 2. Pemberian susu sapi bubuk sebesar 1,8gram/hari selama 56 hari merupakan dosis efektif yang mampu menurunkan kadar MDA jaringan hepar tikus percobaan.

2017-2029.

7. Lin AM, Chen KB, and Chao PL. Antioxidative Effect of Vitamin D3 on Zinc-Induced Oxidative Stress in CNS. Annals of the New York Academy of Sciences. 2005; 1053: 319-329.

8. Wulanti R, Wirakusumah ES, dan Sumarwan U. Karakteristik dan Pola Konsumsi Pangan Penderita Diabetes Melitus yang Obes pada Poliklinik Subbagian Metabolik Endokrin Bagian IImu Penyakit Dalam dan Poliklinik Gizi RSCM, DKI Jakarta. Media Gizi dan Keluarga. 1999; 23(1): 25-29.

9. Amirshahrokhi K, Dehpour AR, Hadjati J, Sotoudeh M, and Ghazi-Khansari M. Methadone Ameliorates Multiple-Low-Dose Streptozotocin-Induced Type. Toxicology and Applied Pharmacology. 2008; 232(1): 119-124.

10. Suriani N. Gangguan Metabolisme Karbohidrat pada Diabetes Melitus. [Tesis]. Universitas Brawijaya, Malang. 2012.

11. Puspati NKS. Anthara MS, dan Dharmayudha AAGO. Pertambahan Bobot Badan Tikus Diabetes Melitus dengan Pemberian Ekstrak Etanol Buah Naga Daging Putih. Indonesia Medicus Veterinus. 2013; 2(2): 225- 
234.

12. Subekti I. Organisasi Diabetes di Indonesia. Di dalam: Soegondo S, Soewondo P, dan Subekti I. Penatalaksanaan Diabetes Melitus Terpadu. Jakarta: Balai Penerbit FKUI; 2009; hal. 231.

13. Nugroho AE. Review: Hewan Percobaan Diabetes Melitus: Patologi dan Mekanisme Aksi Diabetogenik. Biodiversitas. 2006; 7(4): 378-382.

14. Zhang M, Lu XY, Li J, Xu ZG, and Chen L. The Characterization of High-Fat Diet and Multiple LowDose Streptozotocin Induced Type 2 Diabetes Rat Model. Experimental Diabetes Research. 2008; 2008: 9.

15. Carole M. The Role of Vitamins in the Prevention and Treatment of Type 2 Diabetes and Its Complication. Journal of Diabetes Nursing, 2013; 17(10): 376-383.

16. Cândido FG, Ton WT, and Alfenas Rde C. Dairy Products Consumption Versus Type 2 Diabetes Prevention and Treatment; A Review of Recent Findings from Human Studies. Nutrición Hospitalaria. 2013; 28(5): 1384-1395.

17. Gao D, Ning N, Wang C, Wang Y, et al. Dairy Products Consumption and Risk of Type 2 Diabetes: Systematic Review and Dose-Response Meta-Analysis. PLoS ONE. 2013; 8(9).

18. Mallick AK, Maradi R, Joshi VR, Shorey G, and Ahsan M. A Study on Malondialdehyde as a Marker of Lipid Peroxidation in Male and Female Patients with Type 2 Diabetes Melitus. International Journal of Pharmaceutical Sciences Review and Research. 2011; 8(2): 198-201.

19. Erejuwa OO. Oxidative Stress in Diabetes Melitus: Is There a Role for Hypoglycemic Drugs and/or Antioxidant? In: Lushchak VI and Gospodaryov DV (Eds). Oxidative Stress and Diseases. Croatia: In Tech Publication; 2012; p. 217-246.

20. Setyohadi, Baskoro AD, dan Sigit ML. Peranan Minyak Zaitun terhadap Penurunan Kadar Kolesterol LDL dalam Darah. Majalah Kesehatan FKUB. 2006; 1(2).
21. Tangvarasittichai $S$, Poonsub $P$, Tangvarasittichai $O$, and Sirigulsatien V. Serum Level of Malondialdehyde in Type 2 Diabetes Melitus Thai Subjects. Siriraj Medical Journal. 2009; 61: 20-23.

22. Nilsson M, Holst JJ, and Björck IM. Metabolic Effects of Amino Acid Mixtures and Whey Protein in Healthy Subjects: Studies Using Glucose-Equivalent Drinks. The American Journal of Clinical Nutrition. 2007; 85(4): 996-1004.

23. Kalergis M, Leung YSS, and Nedelcu R. Dairy Products and Prevention of Type 2 Diabetes: Implications for Research and Practice. Frontiers in Endocrinology. 2013; 4(90): 1-6.

24. Martini LA and Wood RJ. Milk Intake and the Risk of Type 2 Diabetes Melitus, Hypertension, and Prostate Cancer. Arquivos Brasileiros de Endocrinologia \& Metabologia. 2009; 53(5): 688-694.

25. Aune D, Norat T, Romundstand P, and Vatten LJ. Dairy Products and The Risk of Type 2 Diabetes: A systematic Review and Dose-Response Meta-Analysis of Cohort Studies. America Journal Clinical Nutrition. 2013: 1-18.

26. Baxter AJ, Coyne T, and McClintock C. Dietary Patterns and Metabolic Syndrome-A Review of Epidemiologic Evidence. Asia Pacific Journal of Clinical Nutrition. 2006; 15(2): 134-142.

27. Arkhaesi N. Kadar Malondialdehyde (Mda) Serum sebagai Indikator Prognosis Keluaran pada Sepsis Neonatorum. [Tesis]. Universitas Diponegoro, Semarang. 2008

28. Padalkar R, Shinde AV, and Patil SM. Lipid Profile, Serum Malondialdehyde, Superoxide Dismutase in Chronic Kidney Disease and Type 2 Diabetes Melitus. Biomedical Research. 2012; 23(2): 207-210.

29. Manohar SM, Vaikasuvu SR, Deepthi K, Sachan A, and Narasimha SR. An Association of Hyperglicemia with Plasma Malondialdehyde and Atherogenic Lipid Risk Factor in Newly Diagnosed Type 2 Diabetic Patients. Journal of Research in Medical Sciences. 2013; 18(2): 89-93. 